\title{
Gianotti-Crosti syndrome: a frequent but underdiagnosed rash
}

\author{
Ivo Miguel Neves (B) , Maria Ventura Nogueira, Cláudia Patraquim, \\ Manuela Costa Alves
}

Paediatrics, Hospital de Braga, Braga, Portugal

\section{Correspondence to} Dr Ivo Miguel Neves; ivomiguelgbneves@gmail.com

Accepted 27 July 2021

\section{DESCRIPTION}

We present the case of a healthy 2-year-old child, with irrelevant personal and family history, that was taken to the emergency department for a papulovesicular rash that has developed and evolved over 5 days. It started on the foot, subsequently reaching to the hands, face and remaining integument, with mild pruritus and without interfering with sleep. Concomitantly with the appearance of the lesions, she started fever, lasting 2 days and mentioned food refusal and nasopharyngitis prior to the onset of rash. No other symptoms were associated.

Physical examination showed a papulovesicular rash predominating in the extremities, legs and feet, buttocks and face (figure 1); some crusted lesions on palms (figure 2) and plants. Scalp, genital and anal mucosas were spared. No other major changes were found in the physical examination.

Simple laboratory evaluation was performed and the results did not present major changes, only a slightly elevated sedimentation rate $(25 \mathrm{~mm} /$ hour $)$ and $C$ reactive protein $(7.9 \mathrm{mg} / \mathrm{L})$. Serologies were negative for hepatitis B and C virus, HIV, EpsteinBarr virus (EBV) and Mycoplasma pneumoniae. Parvovirus B19-specific IgG antibodies were negative and IgM was doubtful. Human herpesvirus 6 (HHV-6) DNA was positive in the blood.

The definitive diagnosis of Gianotti-Crosti syndrome (GCS) by HHV-6 was made. This is a self-limited skin eruption, which usually occurs in children under 5 years of age and clinically manifests with papular/papulovesicular rash that may coalesce into plaques, usually in association with viral infections (most often EBV or hepatitis B virus infection), being $H H V-6$ an uncommon cause of GCS. Occasionally, it can occur in association with vaccination or bacterial infections.

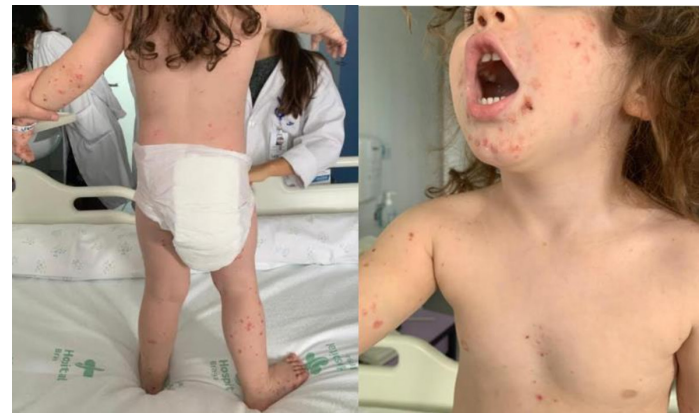

Figure 1 Papulovesicular rash.

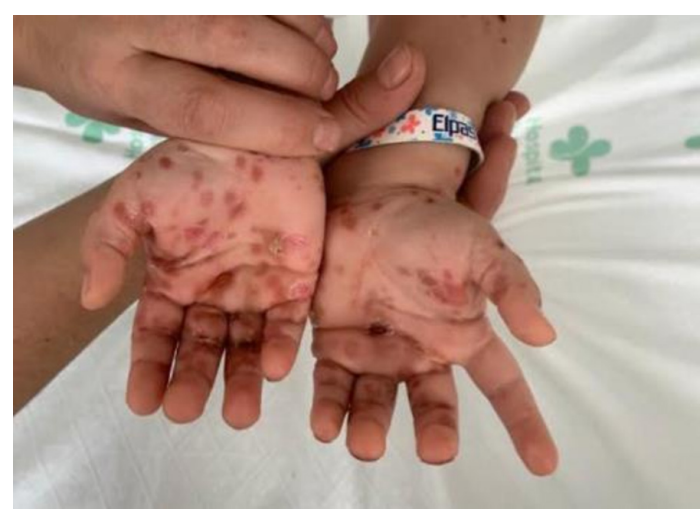

Figure 2 Crusted lesions on palms.

The patients may also present extracutaneous signs and symptoms (eg, malaise, fever, diarrhoea, lymphadenopathy, hepatomegaly).

The diagnosis is clinic and there are no specific laboratory features characteristic of GCS; however, the laboratory tests to identify an aetiologic cause may also be considered in specific situations, for example, patients with extracutaneous clinical findings as in this case report. ${ }^{12}$

The prognosis of GCS is excellent; however, the rash may take time to resolve; it usually resolves spontaneously between 10 days and 6 months, thus, requiring no treatment. ${ }^{3}$

\section{Patient's perspective}

We realised that the cutaneous symptoms were related to a viral infection and that the prognosis was excellent once it is a self-limited cutaneous disorder and the treatment is only symptomatic with pruritus control. We are grateful to the medical team for explaining it in simple words.

\section{Learning points}

Gianotti-Crosti syndrome is a self-limited skin eruption and it is associated with viral infections (most frequent), vaccination or bacterial infections.

- The diagnosis is clinic and the prognosis is excellent.

- The treatment is supportive through the use of emollients/topical antipruritic lotions. 
In case of pruritus, treatment is supportive through the use of emollients/topical antipruritic lotions (provides relief) and oral antihistamines (if the pruritus interferes with sleep and activities of daily living). ${ }^{4}$

It is important to recognise this entity in order to avoid carrying out complementary unnecessary tests for diagnoses.

Contributors IMN: cared for the patient, edited the manuscript, prepared the figures and obtained the written informed consent. MVN, CP and MCA: cared for the patient, edited the manuscript and gave useful discussions.

Funding The authors have not declared a specific grant for this research from any funding agency in the public, commercial or not-for-profit sectors.

Competing interests None declared.

Patient consent for publication Parental/guardian consent obtained.
Provenance and peer review Not commissioned; externally peer reviewed.

\section{ORCID iD}

Ivo Miguel Neves http://orcid.org/0000-0001-6858-6456

\section{REFERENCES}

1 Chuh AA. Gianotti-Crosti syndrome (papular acrodermatitis). UpToDate [Internet], 2019. Available: https://www.uptodate.com/contents/gianotti-crostisyndrome-papulara crodermatitis [Accessed Nov 2020].

2 Nelson JS, Stone MS. Update on selected viral exanthems. Curr Opin Pediatr 2000;12:359-64.

3 Chuh A, Lee A, Zawar V. The diagnostic criteria of gianotti-Crosti syndrome: are they applicable to children in India? Pediatr Dermatol 2004;21:542-7.

4 Boeck K, Mempel M, Schmidt T, et al. Gianotti-Crosti syndrome: clinical, serologic, and therapeutic data from nine children. Cutis 1998;62:271-4; quiz 286.

Copyright 2021 BMJ Publishing Group. All rights reserved. For permission to reuse any of this content visit https://www.bmj.com/company/products-services/rights-and-licensing/permissions/

BMJ Case Report Fellows may re-use this article for personal use and teaching without any further permission.

Become a Fellow of BMJ Case Reports today and you can:

- Submit as many cases as you like

- Enjoy fast sympathetic peer review and rapid publication of accepted articles

- Access all the published articles

- Re-use any of the published material for personal use and teaching without further permission

\section{Customer Service}

If you have any further queries about your subscription, please contact our customer services team on +44 (0) 2071111105 or via email at support@bmj.com.

Visit casereports.bmj.com for more articles like this and to become a Fellow 